\title{
ROSSZINDULATÚ DAGANATOS BETEGEK ÚJ IMMUNTERÁPIÁS KEZELÉSI LEHETŐSÉGEI
}

\section{NEW POSSIBILITIES OF IMMUNE THERAPY IN PATIENTS WITH MALIGNANCIES}

\author{
Géczi Lajos', Liszkay Gabriella², Kásler Miklós ${ }^{3}$ \\ PPhD, központvezetô főorvos, Országos Onkológiai Intézet Gyógyszerterápiás Központ, Budapest, gelajos@oncol.hu \\ ²PhD, osztályvezető fôorvos, Országos Onkológiai Intézet Onko-dermatológiai Oszzály, Budapest \\ ${ }^{3}$ az MTA doktora, egyetemi tanár, miniszter, Emberi Erőforrások Minisztériuma, Budapest
}

\section{ÖSSZEFOGLALÁS}

Az immunterápia a melanóma, tüdődaganat, fej-nyaki daganatok, vesesejtes daganat és Hodgkin-limfóma CTLA-4-, PD-1-, PD-L1-gátló kezelések sikeres alkalmazását követően az onkológia egyik legfontosabb kutatási területévé vált. Ebben az összefoglaló közleményben, elsősorban a szolid daganatos betegségekre korlátozva, áttekintjük az immunterápia legjelentősebb eredményeit. Az immunellenőrzőpont-gátló kezelések mellett röviden bemutatjuk a vakcina, a monoklonális antitest és az antigén-specifikus T-sejt kezelés alkalmazási lehetőségeit is.

\section{ABSTRACT}

Immune therapy has become a major focus of research in oncology, following the recent success of CTLA-4, PD-1 and PD-L1 inhibitors in melanoma, lung cancer, head and neck cancer, renal cell cancer and Hodgkin lymphoma. In this clinical review we provide information regarding advance and main achievements in the immune therapy of different malignant tumours. Beside the new checkpoint inhibitors vaccination, monoclonal antibodies and adoptive cell immunotherapy are presented briefly.

Kulcsszavak: immunterápia, szolid tumor, immunellenőrzés

Keywords: immunotherapy, solid tumour, immune checkpoint

\section{BEVEZETÉS}

Az immunrendszer alapvető szerepe a szervezet külső kórokozók, fertőzések elleni védelme. Az immunrendszer két reakciótípusa a humorális és a celluláris immunválasz, mely a B- és T-limfociták és az általuk termelt produktumok által sza- 
bályozott. A humorális immunválasz a B-sejtek antitest képzése révén semlegesíti és eltávolítja a sejten kívüli mikrobákat, toxinokat. A sejtes immunválasz viszont az intracelluláris mikrobákat távolítja el az antigén felismerése, az antigénprezentáló sejt (APC) aktivációja, majd a T-sejtek proliferációja révén (Kásler, 2018).

\section{DAGANATOS IMMUNITÁS}

Mind a veleszületett, mind a szerzett immunitás jelentős szerepet játszik a daganatellenes immunválaszban. A veleszületett immunsejtek (granulociták, makrofágok, NK-sejtek és dendritikus sejtek) fontos szignálokat szolgáltatnak a B- és T-sejteknek. A szerzett immunválasz elsősorban a B-, a CD8+ citotoxikus T-limfocita (CTL) és CD4+ T-helper sejtekhez köthető. Az APC hidat képez a veleszületett és szerzett immunitás között, azáltal, hogy felismeri és bemutatja az idegen antigént az éretlen T-sejtnek. Az APC a nagy hisztokompatibilitási komplex (MHC) molekula segítségével alkalmas a limfociták aktiválására.

A citotoxikus T-limfocita a performin, granzym és a tumornekrózisfaktor (TNF) szupercsalád ligandján keresztül képes a tumorsejtekre hatni. A CD8+ sejtekből felszabaduló interferon (IFN)-gamma és TNF-alfa tovább segíti az antitumor választ. A natív CD4+ T-sejt aktiválódhat, és különböző T-sejt szubpopulációk alakulnak ki: Th1, Treg (regulatórikus T) stb. A Th1 sejt IFN-gamma és kemokinek képzésével segíti a CD8+ sejtek proliferációját, migrációját, tumorba való infiltrációját. Képes aktiválni a gyulladásos sejteket (makrofágok, granulociták, NK-sejtek) a daganat körül. Az NK-sejt (természetes ölősejt) alkalmas a daganatsejtek direkt elpusztítására, kemokin, citokin és növekedési faktor képzésére. A makrofágok az apoptotikus tumorsejteket takarítják el, a tumor sztróma és a tumorasszociált immundiszfunkció fontos elemeit képezik.

A jelenlegi elmélet szerint az immunrendszer képes spontán felismerni a kialakult daganatsejteket, és specifikus citotoxikus válasz útján eliminálni azokat (immuno-surveillance). A korai eliminációs fázisban a veleszületett és szerzett immunitás elpusztítja a daganatsejteket. Az equilibrium fázisában egyensúly alakul ki a daganat és az immunválasz között, amikor a sporadikusan kialakult daganatsejtek egy része túléli az immunrendszer támadását. Az escape fázisban az immunrendszer nem képes a daganatsejteket megfékezni, megállíthatatlan progresszió alakul ki (Zhang-Chen, 2018).

\section{A DAGANATOS IMMUNVÁLASZ SZABÁLYOZÁSA}

Az egészséges immunrendszer müködése megkívánja, hogy az immunválasz megfelelő, beépített gátlómechanizmusokkal szabályozható legyen, ami biztosítja a szervezet immunhomeosztázisát. A daganatellenes immunválasz első és szüksé- 
ges lépése a tumor antigén felismerése. Az ismert tumorasszociált antigén (TAA) molekulák többféle daganatban is előfordulhatnak. A tumor neoantigén a daganat keletkezése, proliferációja során kialakult mutációk terméke, mely adott daganattípusra specifikus, és amit a szervezet immunrendszere testidegenként felismerhet. Minél több mutáció, illetve neoantigén van jelen egy daganatban, annál nagyobb a valószínűsége, hogy a szervezet hatékony immunválaszt indíthat ellene.

Az APC a fó hisztokompatibilitási komplexhez kapcsoltan bemutatja az általuk felismert antigén fragmentumot az éretlen T-sejtnek. Az aktiváláshoz további kostimulációs szignálokra van szükség. Ilyen szignál a CD28 T-sejt felszíni receptor és az APC-n elhelyezkedő B7-1 (CD80) és B7-2 (CD86) kostimulációs molekulák közötti kölcsönhatás. A CD28 ligand kötés aktiválja a T-sejteket, azonban szintén a molekulához kapcsolódni képes CTLA-4 receptor és B7 kötődés gátló hatást vált ki. A CTLA-4 ellenes monoklonális antitestek úgy aktiválják a T-sejteket, hogy blokkolják a CTLA-4 gátló hatását a T- és Treg-sejteken, ami a T-sejt aktiválásához, proliferációjához és a limfociták tumorba történő infiltrációjához vezet, a daganatsejtek pusztulását eredményezve (Guo-Tsung, 2017).

A programozott sejthalál receptor (PD-1) egy immunellenőrző receptor, amely jelen van a CD4+, CD8+, Treg-, B- és NK-sejteken. Két liganduma (a receptor által kötött molekula) a PD-L1 és PD-L2. A makrofágokon és dendritikus sejteken a PD-L2 jelenik meg elsősorban, amit az interferon-alfa, interleukin-4 és a toll-like receptor liganduma növelhet. A PDL-1 és/vagy PDL-2, valamint a PD-1 kapcsolódása gátolja a CD4+ és a CD8+ sejtek funkcióját, ezáltal a periférián a daganatellenes immunválaszt. A PD-L1 a T- és B-limfociták, makrofágok, és dendritikus sejtek mellett a daganatsejteken is jelen lehet. Az interferon-alfa, az interleukin-4 és interleukin-10 segíti a PD-L1 expresszióját. Az expresszió függhet inflammatorikus szignáloktól, így a tumorsejteken és a tumort infiltráló immunsejteken adaptív PD-L1 expresszió jön létre, de szabályozhatják onkogén szignálok is, konstitutív PD-L1 expressziót eredményezve. A PD-L1 célzott gátlásával megelőzhető a T-sejtek aktivitásának gátlása, a PD-L2/PD-1 interakció megtartott marad, így potenciálisan megőrizhető az immunhomeosztázis (Géczi et al., 2016, Rouanne et al., 2018).

\section{VAKCINÁK}

Alkalmazásuk során elölt tumorsejtekkel vagy tumor antigénekkel aktív immunizálást végeznek. A cél a szervezet immunrendszerének aktiválása a daganatsejtek ellen az antigének prezentálásával. A hepatitis B-vírus és a humán papillomavírus ellenes vakcinák alkalmazása során a T-sejtek eliminálják a sporadikus daganatsejteket, ezáltal megelőzik a daganatos betegségek kialakulását. Prosztatarákban 
fúziós fehérjét alkalmaznak, mely tartalmazza a prosztatasejtek által termelt savi foszfatáz enzimet mint antigént. Monocitákat, éretlen dendritikus sejteket vonnak ki a beteg véréből, és a fúziós antigénnel történő aktiválás után (ex vivo) juttatják vissza a szervezetbe. Az ily módon alkalmazott kezelés hatékonynak bizonyult áttétes, kasztráció-rezisztens (hagyományos hormonkezelésre nem reagáló) panaszmentes vagy kevés tünettel járó betegekben. Európában nem törzskönyvezték, az USA-ban alkalmazzák. A daganatok gyógyításában a vakcinakezelés alkalmazása nagyobb áttörést nem eredményezett.

\section{MONOKLONÁLIS ANTITESTEK}

A daganatsejt felületén levő receptorokhoz vagy sejtspecifikus antigénekhez kapcsolódnak. Az első esetben a daganat növekedéséért és terjedéséért felelős receptor blokkolása révén, a monoklonális antitest ( $\mathrm{mAb}$ ), a malignus progresszió gátlásán túl specifikus immunológiai reakciót indít el, ami a daganat pusztulásához vezet. Ezt használjuk ki például HER2 receptor+ emlő- és gyomordaganat kezelése során. Másik esetben sejtfelszíni receptorhoz kapcsolódó mAb a hozzákapcsolt citotoxikus vagy radioaktív anyaggal célzottan a daganatos sejteket pusztítja el, és következményes immunreakciót indít el. A két antigén kötőhellyel rendelkező (bispecifikus) mAb képes kötődni a tumor- és immunsejthez egyaránt, biztosítva a közvetlen kapcsolatot daganat és immunrendszer között (Martin-Liberal et al., 2017).

\section{A TUMORASSZOCIÁLT ANTIGÉNSPECIFIKUS T-SEJT KEZELÉS}

Az adaptív T-sejt terápia új, ígéretes immunterápiás lehetőség, hematológiai betegségekben és szolid tumorokban egyaránt. Melanomában tumort infiltráló limfociták (TIL) alkalmazásával próbálkoztak. A TIL-sejteket dúsítás után viszszajuttatták a betegbe, és tumorregressziót észleltek. A módszer hátránya, hogy nem minden daganatból lehet TIL-sejteket kinyerni, és nehéz nagyszámú, élő és hatékony TIL-sejtet elóállítani. A probléma megoldását a CAR-T-sejt (chimeric antigen receptor) technológia alkalmazása jelentheti. Perifériás vérből nyert limfocitákba retrovírus vagy lentivírus segítségével tumorantigén-specifikus T-sejt receptor gént ültetnek be, melyet követően a kellő számban dúsított T-sejtek (CART-sejtek) képesek a tumort felismerni és elpusztítani. Melanómában reménykeltő eredményeket közöltek. A folyamat az MHC-rendszerhez kötött. A második generációs CAR-sejtek az MHC-rendszertől függetlenül képesek felismerni a sejtspecifikus antigéneket, mert felületükön az antigénkötő ellenanyaglánc ennek megfelelően lett kialakítva (Steuer-Ramalingam, 2018). 


\section{IMMUNELLENŐRZŐ PONTOKAT BLOKKOLÓ ANTITESTEK}

Az immun-ellenőrzőpontokat blokkoló antitestek (IPB) alkalmazása számos szolid daganatos betegség kezelését alapjában változtatta meg (Torphy et al., 2017). Jelenleg is több klinikai vizsgálatot végeznek az ideális alkalmazás, dózis és szekvencia megállapítására. Az EMA (Európai Gyógyszerügynökség) által szolid daganatokban jóváhagyott és javasolt készítményeket és indikációkat a 1. táb-

1. táblázat. Az EMA által regisztrált immunellenőrzőpont-gátló készítmények daganattípusok szerint

\begin{tabular}{|c|c|c|}
\hline & Indikáció & Regisztráció éve \\
\hline \multicolumn{3}{|c|}{ CTLA-4 inhibitorok } \\
\hline ipilimumab & melanoma & 2010 \\
\hline ipilimumab + nivolumab kombináció & melanoma & 2017 \\
\hline \multicolumn{3}{|c|}{ PD-1 inhibitorok } \\
\hline \multirow{7}{*}{ nivolumab } & melanoma & 2015 \\
\hline & laphámsejtes NSCLC* & 2015 \\
\hline & nem laphámsejtes NSCLC* & 2016 \\
\hline & vese-sejtes tumor & 2016 \\
\hline & $\mathrm{cHL} * *$ & 2016 \\
\hline & fej-nyak tumor & 2017 \\
\hline & urothelialis tumor & 2017 \\
\hline \multirow{5}{*}{ pembrolizumab } & melanoma & 2015 \\
\hline & NSCLC*-másodvonal & 2016 \\
\hline & NSCLC* $(>50 \%$ PD-L1) első vonal & 2017 \\
\hline & $\mathrm{cHL}^{* *}$ & 2017 \\
\hline & urothelialis tumor & 2017 \\
\hline \multicolumn{3}{|c|}{ PD-L1 inhibitors } \\
\hline \multirow{2}{*}{ atezolizumab } & urothelialis tumor & 2017 \\
\hline & NSCLC*-másodvonal & 2015 \\
\hline avelumab & Merkel-sejtes tumor & 2017 \\
\hline
\end{tabular}

* NSCLC - nem kissejtes tüdőrák

***HL - klasszikus Hodgkin-limfóma (saját szerkesztés) 
lázatban foglaltuk össze (Géczi et al., 2017; Yarchoan et al., 2017). Az IPB-készítmények alkalmazhatóak egymással kombináltan, de hagyományos onkológiai kezelésekkel is. Tüdődaganatban igazolt, hogy a mütét után adjuvánsan alkalmazott durvalumab a progressziómentes túlélést jelentősen megjavította. A kemoterápia, a célzott kezelés és radioterápia, valamint az IPB-gyógyszerek együttes alkalmazása több szolid daganatban vizsgálat tárgya.

Az immunterápia forradalmasította számos daganat kezelését, ami a daganatok gyógyszeres kezelésében alapvető szemléletváltást igényel. A jelenleg folyó klinikai kutatások eredményei tovább javíthatják az eddig nehezen kezelhető daganatos betegek életkilátásait.

\section{IRODALOM}

Géczi L. - Ladányi A.- Vajdics T. et al. (2016): Immunterápia az urológiai daganatok kezelésében. Magyar Onkológia, 60, 41-45. https://huon.hu/2016/60/1/0041/0041a.pdf

Géczi L. - Nagyiványi K.- Maráz A. (2017): Immunterápia a vesedaganatok kezelésében. Magyar Onkológia, 61, 126-131. http://publicatio.bibl.u-szeged.hu/12048/1/0126a.pdf

Guo, H. - Tsung, K. (2017): Tumor Reductive Therapies and Antitumor Immunity. Oncotarget, 8: 55736-55749. DOI: 10.18632/oncotarget.18469, https://www.ncbi.nlm.nih.gov/pmc/articles/ PMC5589695/

Kásler M. (szerk.) (2018): Az onkológia alapjai. Budapest: Medicina Könyvkiadó Zrt.

Martin-Liberal, J. - Ochoa de Olza, M. - Hierro, C. et al. (2017): The Expanding Role of Immunotherapy. Cancer Treatment Review, 54, 74-86. DOI: 10.1016/j.ctrv.2017.01.008, https://www. researchgate.net/publication/313619715_The_Expanding_Role_of_Immunotherapy

Rouanne, M. - Roumiguié, M. - Houédé, N. et al. (2018): Development of Immunotherapy in Bladder Cancer: Present and Future on Targeting PD(L)1 and CTLA-4 Pathways. World Journal of Urology, DOI: 10.1007/s00345-018-2332-5

Steuer, C. E. - Ramalingam, S. S. (2018): Tumor Mutation Burden: Leading Immunotherapy to the Era of Precision Medicine? Journal of Clinical Oncology, 36, 631-632. DOI: 10.1200/ JCO.2017.76.8770, https://ascopubs.org/doi/full/10.1200/JCO.2017.76.8770?url_ver=Z39.88-2003 \&rfr_id $=$ ori\%3Arid\%3Acrossref.org\&rfr_dat $=$ cr_pub\%3Dpubmed

Torphy, R. J. - Schulick, R. D. - Zhu, Y. (2017): Newly Emerging Immune Checkpoints: Promises for Future Cancer Therapy. International Journal of Molecular Sciences, 6, pii: E2642. DOI: 10.3390/ijms18122642, https://www.mdpi.com/1422-0067/18/12/2642

Yarchoan, M. - Hopkins, A. - Jaffee, E. M. (2017): Tumor Mutational Burden and Response Rate to PD-1 Inhibition. The New England Journal of Medicine, 21, 2500-2501. DOI:10.1056/NEJMc1713444, https://www.ncbi.nlm.nih.gov/pmc/articles/PMC6549688/

Zhang, H. - Chen, J. (2018): Current Status and Future Directions of Cancer Immunotherapy. Journal of Cancer, 9, 1773-1781. DOI: 10.7150/jca.24577, http://www.jcancer.org/v09p1773. htm 